\title{
Effects of GnRH analogues on pituitary-testicular function in free-ranging African elephants (Loxodonta africana)
}

\author{
J. L. Brown ${ }^{1,2}$, M. Bush ${ }^{1}$, D. E. Wildt ${ }^{1}$, J. R. Raath ${ }^{3}$, V. de Vos ${ }^{3}$ and \\ J. G. Howard ${ }^{\mathrm{I}}$ \\ ${ }^{1}$ Department of Animal Health, National Zoological Park, Smithsonian Institution, Washington, DC \\ 20008, USA; ${ }^{2}$ Conservation and Research Center, Front Royal, VA 22630, USA; and ${ }^{3}$ Kruger \\ National Park, Skukuza 1350, Republic of South Africa
}

\begin{abstract}
We tested the ability of several GnRH analogues to suppress pituitary-testicular activity and potentially musth in free-ranging African elephants (Loxodonta africana). In Study 1 , adult bulls were given 4 or $12 \mathrm{mg} \mathrm{GnRH}$ antagonist (Detirelix) or saline i.m. on day 0 ( $n=3$ bulls per treatment). Animals were then recaptured on day 2 (about $48 \mathrm{~h}$ later) and given $300 \mu \mathrm{g}$ GnRH i.v. to assess the ability of the antagonist to block pituitary activity. Detirelix reduced $(P<0.05)$ basal concentrations of serum LH and testosterone on day 2 compared with day 0 , with no effect of dose. Similarly, LH and testosterone release induced by GnRH were also reduced $(P<0.05)$ in the Detirelix-treated bulls $(50-70 \%$ reduction in peak concentrations). In Study 2, elephants were given $30 \mathrm{mg}$ of a structurally similar $\mathrm{GnRH}$ antagonist (103-201$40 ; n=6$ ), $22.5 \mathrm{mg}$ of a long-acting $\mathrm{GnRH}$ agonist (Lupron Depot; $n=4$ ) or D-mannitol carrier $(n=4)$ i.m. on day 0 . All bulls were recaptured and given $\mathrm{GnRH}$ on day 2 (103-20140 treatment) or on days 2 and 20 (Lupron Depot treatment) after the initial injection. In contrast to Detirelix, 103-201-40 did not inhibit basal or GnRH-induced LH or testosterone secretion. Pituitary-testicular responses to Lupron Depot were initially stimulatory, as evidenced by increased $(P<0.05) \mathrm{LH}$ and testosterone secretion on days 0 and 2 . By day 20 , basal $\mathrm{LH}$ concentrations had returned to baseline values and the response to $\mathrm{GnRH}$ was markedly reduced $(P<0.05)$, indicating that the pituitary was at least partially desensitized. Basal testosterone concentrations had also returned to baseline values by day 20 after Lupron Depot treatment. However, despite the attenuated LH response to $\mathrm{GnRH}$, subsequent testosterone secretion was increased $(P<0.05)$ compared with controls, suggesting the testes of agonist-treated bulls had, instead, become hyper-responsive to small increases in LH secretion. These results suggest that $\mathrm{GnRH}$ analogues can suppress the pituitary-gonadal axis in African elephants; however, longer treatment periods, more frequent injection intervals or higher doses are probably needed to inhibit testosterone secretion completely and, thus, musth.
\end{abstract}

\section{Introduction}

The phenomenon of musth has been recognized for centuries to occur in the Asian elephant (Elephas maximus) and, more recently in the African elephant (Loxodonta africana) (Poole and Moss, 1981; Hall-Martin and van der Walt, 1984). Musth occurs annually or biannually in most adult bulls and, although not absolutely necessary for breeding, it is regarded as an important reproductive strategy (Eisenberg et al, 1971; Jainudeen et al., 1972a; Poole and Moss, 1981; Poole, 1987, 1989a, b; Hall-Martin, 1987). In general, males in musth experience a temporary rise in dominance rank, are more successful at courting and mating oestrous females, and travel long distances for breeding, thus ensuring outbreeding and the transmission of genetic material. From a management standpoint, however,

Received 15 February 1993 musth bulls create serious problems because of associated increases in aggressive and unpredictable behaviour (Eisenberg et al., 1971; Jainudeen et al., 1972a). Captive elephants in musth have severely injured and even killed handlers, whereas, free-living musth bulls often threaten human life and property.

Present methods for controlling musth in captive elephants include isolation and reducing food and water intake, actions that could elicit animal welfare concerns. Although castration offers a permanent solution, the surgery is both difficult and often unacceptable since some bulls may eventually be needed for breeding. Because musth appears to be related to high circulating testosterone concentrations (Jainudeen $e$ t al, 1972b; Hall-Martin and van der Walt, 1984; Howard et al, 1984; Rasmussen et al., 1984; Hall-Martin, 1987; Cooper et al., 1990), any therapy that temporarily suppresses pituitary LH release and subsequent testosterone secretion might alleviate behaviour problems until the musth cycle ends. Several analogues iour problum from Bioscientifica.com at 04/26/2023 10:37:34AM Down hoaded from Bioscientifica.com at 04/26/2023 10:37:34AM
via free access 
of $\mathrm{GnRH}$ have been shown to suppress $\mathrm{LH}$ and testosterone secretion in domestic and laboratory animals (Vickery et al., 1984; Mann et al., 1985; Lincoln et al., 1986) and humans (Labrie et al., 1980), and for this reason are being considered as possible male contraceptives (Bremner et al., 1991; Pavlou et al., 1991). Because of their antigonadotrophic activity, it is possible that these compounds might similarly inhibit endocrine function during periods of musth in the bull elephant. As a first step to considering this approach as a means of controlling musth, our objectives were to evaluate the effectiveness of two GnRH antagonists and a $\mathrm{GnRH}$ agonist to reduce $\mathrm{LH}$ and testosterone secretion acutely in mature bull elephants. We chose to conduct these studies using free-ranging males living in the Kruger National Park because of the scarcity of adult bull elephants in captivity.

\section{Materials and Methods}

\section{GnRH analogues}

In Study 1, a GnRH antagonist provided by B. Vickery (Syntex Research, Palo Alto, CA) (Detirelix; RS-68439) was used. In Study 2, Detirelix was unavailable; therefore, a second antagonist (103-201-40), synthesized by the Salk Institute (San Diego, CA) (NIH contract No1-HD-2-2824), was made available by M. Karten of the Contraceptive Development Branch, Center for Population Research, National Institutes of Health, Bethesda, MD. The two antagonist peptides are similar in structure except that Detirelix [Ac-D-Nal ${ }^{1}, \mathrm{D}-4-\mathrm{Cl}-\mathrm{Phe}^{2}, \mathrm{D}-\mathrm{Trp}^{3}, \mathrm{D}-$ $\mathrm{hArg}\left(\mathrm{Et}_{2}{ }^{6}, \mathrm{D}-\mathrm{Ala}{ }^{10}-\mathrm{GnRH}\right]$ has a D-diethylhomoarginine in the sixth position, whereas 103-201-40 (Ac-D-Nal ${ }^{1}$, D-4-Cl-Phe ${ }^{2}$, D$\left.\mathrm{Trp}^{3}, \mathrm{D}-\mathrm{Arg}^{6}, \mathrm{D}-\mathrm{Ala}^{10}-\mathrm{GnRH}\right)$ has a D-arginine. Detirelix and 103-201-40 may have similar potencies (M. Karten, personal communication). For injection, the antagonists were suspended in saline (Detirelix) or 2.5\% D-mannitol (103-201-40). The GnRH agonist, Lupron Depot (leuprolide acetate; D-Leu' ${ }^{6}$-Des Gly ${ }^{10}$-NHEt-GnRH), was provided by J. Seely, Takeda-Abbott, Abbott Park, IL, and supplied as sterile, lyophilized microspheres (leuprolide acetate incorporated in a biodegradable copolymer of lactic and glycolic acids) that formed a suspension when mixed with diluent (carboxymethylcellulose sodium, D-mannitol, polysorbate 80 and water).

\section{Animals and blood collection}

Study I was conducted in the Kruger National Park in October-November and Study 2 in April-May. Although it was not possible to obtain individual body weights, all bulls were considered adult. Mean ( \pm SEM) body measurements were as follows: shoulder height $(312 \pm 4 \mathrm{~cm}$; range, $260-334 \mathrm{~cm}$ ), chest girth ( $427 \pm 7 \mathrm{~cm}$; range, $364-452 \mathrm{~cm})$ and body length $(304 \pm 7 \mathrm{~cm}$; range, $222-334 \mathrm{~cm})$. There were no differences $(P>0.05)$ among body measurements between studies.

Bull elephants, free-ranging in bachelor herds of one to four animals, were approached by helicopter and anaesthetized with a remotely delivered dart injection of $15 \mathrm{mg}$ etorphine- $\mathrm{HCl}$ (M99; Reckitt and Coleman, Hull). A surgical plane of anaesthesia was maintained with supplemental i.v. injections of this same drug. All animals were fitted with radiocollars (Telonics, Inc., Mesa, AZ) to facilitate relocation and capture. Blood samples were collected at intervals of $5 \mathrm{~min}$ for $90 \mathrm{~min}$ via an indwelling catheter inserted into an ear vein. All treatments were administered after the third blood sample. GnRH analogues were administered i.m. by first inserting a 14-gauge, $4 \mathrm{~cm}$ long needle through the hide into the muscle and then inserting a 16gauge, $10 \mathrm{~cm}$ long injection needle through the 14-gauge needle. To ensure complete delivery, injections were followed by a $3 \mathrm{ml}$ saline flush through the 16-gauge needle. After the last blood sample, anaesthesia was reversed with an i.v. injection of $40 \mathrm{mg}$ diprenorphine- $\mathrm{HCl}$ (Revivon: Reckitt and Coleman), and animals were observed until they stood up and walked away. Blood samples were kept cool on ice until serum was separated from cells by centrifugation $(1000 \mathrm{~g}, 15 \mathrm{~min}$ ) about $6 \mathrm{~h}$ after collection. Serum was frozen and stored on dry ice until transported to the United States in full compliance with US Fish and Wildlife and CITES regulations.

Musth $(n=2)$ and non-musth ( $n=23)$ bulls were evaluated. Animals in musth were identified as those displaying temporal gland secretions, urine dribbling (with associated staining on the medial aspect of the rear legs) and having a strong odour (Poole and Moss, 1981).

\section{Experimental protocol}

Study 1. Nine elephants were evaluated. On day 0 , each animal was injected i.m. with 4 or $12 \mathrm{mg}$ Detirelix (in $6 \mathrm{ml}$ saline) or saline $(6 \mathrm{ml})(n=3$ bulls per treatment). On day 2 (about $48 \mathrm{~h}$ later), all animals were recaptured and challenged with $\mathrm{GnRH}(300 \mu \mathrm{g}$, i.v.; $6 \mathrm{ml}$ ) to assess the ability of the antagonist to block pituitary function. One musth bull was found and included in the treatment group receiving $12 \mathrm{mg}$ Detirelix.

Study 2. In this study, 14 bull elephants were given $6 \mathrm{ml} \mathrm{D-}$ mannitol carrier $(n=4), 30 \mathrm{mg} \mathrm{GnRH}$ antagonist 103-201-40 $(n=6)$ or Lupron Depot (equivalent to $22.5 \mathrm{mg}$ leuprolide acetate; $n=4$ ) i.m. on day 0 . The results of Study I showed that Detirelix had not completely suppressed pituitary-testicular function; a higher dose of antagonist (103-201-40) was therefore chosen for this study. All antagonist-treated bulls were recaptured on day 2 and administered a GnRH challenge $(300 \mu \mathrm{g} ; 6 \mathrm{ml}$ i.v.). Because of its different mechanism of action (initial pituitary stimulation followed by desensitization), Lupron Depot-treated bulls were recaptured and given $\mathrm{GnRH}$ challenges on days 2 and 20. For comparative purposes, four additional non-musth elephants were anaesthetized once and given a GnRH challenge on day 0 (day $0 \mathrm{GnRH}$ control), and the results compared with animals challenged with $\mathrm{GnRH}$ on day 2 to determine whether repeated capture or anaesthesia affected pituitary-testicular responsiveness. One musth bull was found and given D-mannitol carrier on day 0 and challenged with $\mathrm{GnRH}$ on day 2 . This animal was further evaluated by administering Lupron Depot after the last blood sample on day 2 and given $\mathrm{GnRH}$ challenges on days 2 and 20 after Lupron Depot treatment.

\section{Radioimmunoassays}

All assays were validated for use with elephant serum by demonstrating significant recovery of mass and parallelism 

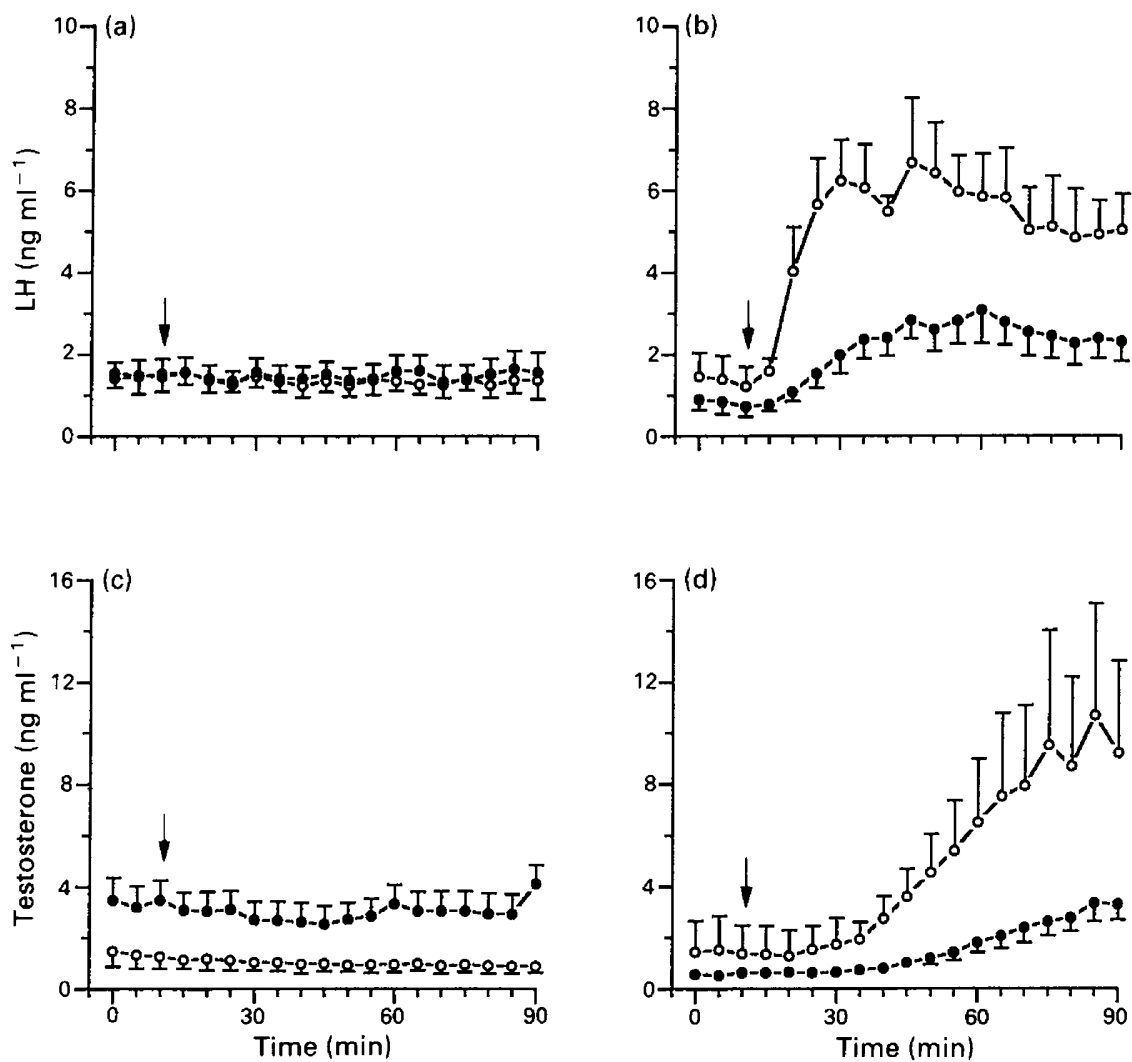

Fig. 1. Mean ( \pm SEM) serum $(a, b)$ LH and $(c, d)$ testosterone concentrations in non-musth bull elephants administered $(O)$ saline $(n=3$ ) or $(O) \mathrm{GnRH}$ antagonist (Detirelix; $n=6$ ), i.m. on day $0(\mathrm{a}, \mathrm{c})$ and given GnRH $(300 \mu \mathrm{g}$ i.v.) on day $2(\mathrm{~b}, \mathrm{~d})$. Blood samples were collected at intervals of $5 \mathrm{~min}$ for $90 \mathrm{~min}$ and all treatments administered after the third sample (arrow).

between serial dilutions of pooled elephant serum and the standard curve. Serum LH was measured using a heterologous radioimmunoassay, with an anti-bovine $\mathrm{LH}$ antiserum (JJR 5; provided by J. Reeves, Washington State University, Pullman, WA), [ ${ }^{125}$ I]-labelled ovine LH (LER-1056-C2; provided by L. Reichert Ir, Albany Medical College, Albany, NY) and ovine LH standard (NIADDK-LH-S18; provided by the National Hormone and Pituitary Program, Baltimore, MD). After adding $0.025,0.05,0.1,0.2,0.4,0.8$ and $1.6 \mathrm{ng}$ ovine $\mathrm{LH}$ to $50 \mu \mathrm{l}$ serum and subtracting endogenous ligand, $0.021,0.06,0.13,0.18$, $0.43,0.77$ and $1.58 \mathrm{ng}$ were recovered $(y=0.98 x+0.009$; $r=0.99$ ). Assay sensitivity (at $90 \%$ binding) was $0.1 \mathrm{ng} \mathrm{ml}^{-1}$ for $200 \mu \mathrm{l}$ serum. Intra- and interassay coefficients of variation were 7.6 and $9.1 \%$, respectively.

Serum testosterone was measured in unextracted serum using antisera and $\left.{ }^{125} \mathrm{I}\right]$-labelled testosterone purchased from ICN Biomedicals (Carson, CA). Upon adding 0.1, 0.25, 0.5, 1.0, 2.5 and $5.0 \mathrm{ng}$ testosterone $\mathrm{ml}^{-1}$ to $25 \mu \mathrm{l}$ serum, and after subtracting endogenous hormone, $0.12,0.26,0.47,1.22,2.88$ and $4.95 \mathrm{ng} \mathrm{ml}^{-1}$ were recovered $(y=1.00 x+0.09 ; r=0.99)$. Because of high testosterone concentrations in serum from musth bulls, samples were diluted 1:10 with phosphate buffer $\left(0.01 \mathrm{~mol} \mathrm{l}^{-1}, \mathrm{pH} 7.4\right)$ before analysis. Diluted samples of pooled musth bull serum also produced displacement curves parallel to the standard curve. The assay sensitivity was $0.05 \mathrm{ng}$ $\mathrm{ml}^{-1}$ for $50 \mu \mathrm{l}$ of serum, and the intra- and interassay coefficients of variation were 6.4 and $7.8 \%$, respectively.

\section{Statistical analysis}

Data were analysed by analysis of variance. $\mathrm{LH}$ and testosterone responses to treatment were evaluated as peak height, net peak height (greatest post-treatment concentration minus pretreatment concentration) and net area under the response curves as previously described (Brown et al., 1988). Basal hormone concentrations were calculated as the mean of all samples (saline treatment on day 0 ) or as the mean of the initial three pretreatment samples ( $\mathrm{GnRH}$ or $\mathrm{GnRH}$ analogue treatments). Upon detection of a significant effect, differences among treatment groups were determined using Duncan's new multiple range tests or Student's $t$ tests. Differences for hormonal data between days 0 and 2 were determined using paired $t$ tests, allowing each animal to serve as its own control. Data are presented as means \pm SEM.

\section{Results}

\section{Study 1}

Hormonal responses to both doses of Detirelix in non-musth bulls were similar $(P>0.05)$; data were therefore pooled for presentation (Fig. 1). On day 0, Detirelix administration had no effect $(P>0.05)$ on $\mathrm{LH}$ or testosterone secretion over the period when blood samples were taken. Concentrations of $\mathrm{LH}$ 


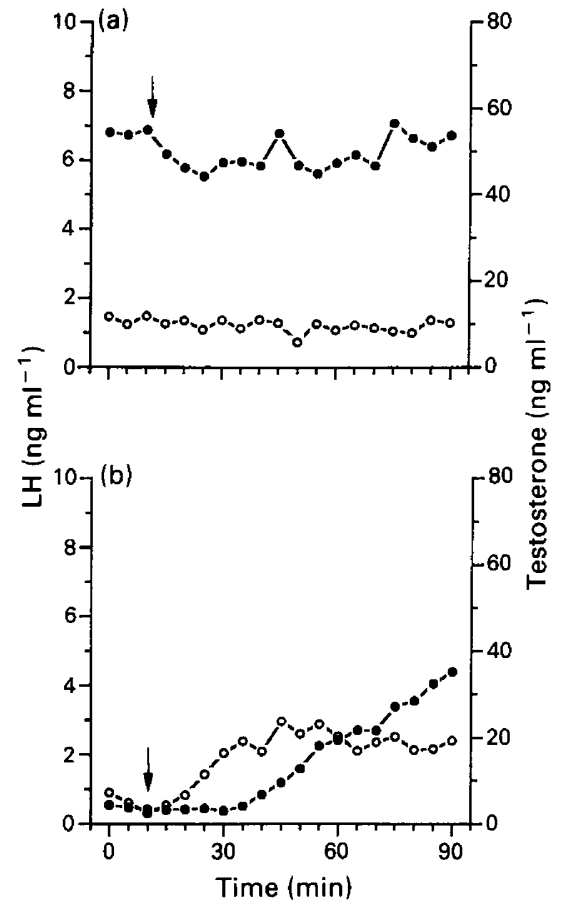

Fig. 2. Serum (O) LH and $(O)$ testosterone concentrations in a musth bull elephant administered $12 \mathrm{mg}$ Detirelix i.m. on (a) day 0 and (b) given GnRH ( $300 \mu \mathrm{g}$ i.v.) on day 2. Blood samples were collected at intervals of $5 \mathrm{~min}$ for $90 \mathrm{~min}$ and all treatments administered after the third sample (arrow).

in Detirelix-treated bulls were similar $(P>0.05)$ to those observed in saline-treated animals (Fig. 1a), whereas concentrations of testosterone were inexplicably higher $(P<0.05)$ before and after Detirelix treatment (Fig. Ic). There were no differences $(P>0.05)$ in basal testosterone concentrations between day $0\left(1.38 \pm 0.26 \mathrm{ng} \mathrm{m}^{-1}\right)$ and day 2 (1.46 \pm $0.59 \mathrm{ng} \mathrm{ml}^{-1}$ ) in saline-treated bulls. In contrast, basal testosterone concentrations in Detirelix-treated animals were lower $(P<0.05)$ on day $2\left(0.59 \pm 0.16 \mathrm{ng} \mathrm{ml}^{-1}\right)$ compared with values measured on day $0\left(3.18 \pm 0.41 \mathrm{ng} \mathrm{ml}^{-1}\right)$ (Fig. Ic, d). Similarly, on day 2 , LH (peak height, $3.08 \pm 0.81$ versus $6.68 \pm 1.57 \mathrm{ng} \mathrm{ml}^{-1}$ ) and testosterone (peak height, $3.31 \pm$ 0.62 versus $10.69 \pm 4.37 \mathrm{ng} \mathrm{ml}^{-1}$ ) responses to GnRH were less $(P<0.05)$ in Detirelix-treated than in saline-treated bulls (Fig. Ib, d).

The one bull suspected of being in musth based on the criteria described had high testosterone concentrations (approximately $50 \mathrm{ng} \mathrm{ml}^{-1}$; Fig. 2a) compared with non-musth bulls (overall mean, $2.25 \pm 0.59 \mathrm{ng} \mathrm{ml}^{-1}$; Fig. Ic). These high concentrations were apparently unrelated to increased basal gonadotrophin secretion, because LH concentrations (Fig. 2a) were similar to those observed in non-musth bulls (Fig. Ia). Treatment of the musth bull with Detirelix had no effect on basal $\mathrm{LH}$ or testosterone secretion on day 0 . However, by day 2 , testosterone concentrations were markedly reduced and the animal no longer appeared to be in musth (Fig. 2b). After the GnRH challenge, LH concentrations increased to a peak of $2.95 \mathrm{ng} \mathrm{ml}^{-1}$ (Fig. 2b), within the range of that observed for the Detirelix-treated non-musth bulls, but less than the GnRH- induced LH surge in saline-treated males (Fig. Ib). Although the LH response was attenuated in the antagonist-treated musth bull, testosterone secretion increased markedly (more than $30 \mathrm{ng} \mathrm{ml}^{-1}$; Fig. $2 \mathrm{~b}$ ), exceeding the response observed in salinetreated non-musth bulls (Fig. Id).

\section{Study 2}

Results of the GnRH challenge on day 0 (data not graphically presented) demonstrated that peak concentrations of $\mathrm{LH}$ $\left(3.51 \pm 0.19 \mathrm{ng} \mathrm{ml}^{-1}\right)$ and testosterone $\left(8.55 \pm 0.84 \mathrm{ng} \mathrm{ml}^{-1}\right)$ were similar $(P>0.05)$ to those observed in animals recaptured and given $\mathrm{GnRH}$ on day 2 (LH, $3.49 \pm 0.56$; testosterone, $8.60 \pm 2.15 \mathrm{ng} \mathrm{ml}^{-1}$; Fig. $\left.3 \mathrm{~b}, \mathrm{e}\right)$, indicating that repeated capture or anaesthesia did not affect pituitary responsiveness.

In contrast to the results obtained for Detirelix in Study 1, basal and $\mathrm{GnRH}$-stimulated $\mathrm{LH}$ and testosterone profiles were not reduced $48 \mathrm{~h}$ after administering $30 \mathrm{mg}$ of the GnRH antagonist 103-201-40 (Fig. 3b, e). However, the GnRH agonist Lupron Depot markedly altered pituitary-testicular function beginning on day 0 (Fig. 3a, d). Within approximately 35 min of injection, $\mathrm{LH}$ concentrations in serum increased above baseline values, reaching $7.19 \pm 1.08 \mathrm{ng} \mathrm{m}^{-1}$ by the end of the sampling period. On day 2 , serum $\mathrm{LH}$ was still higher $(P<0.05)$ in the treatment than the control group, but the net response to native $\mathrm{GnRH}$ was attenuated compared to mannitol- and antagonist-treated bulls (Fig. 3b). By day 20 after Lupron Depot injection, serum LH had returned to baseline concentrations, and the response to GnRH was negligible (Fig. 3c). On day 0 , testosterone concentrations increased within approximately $10 \mathrm{~min}$ of the Lupron Depot-induced rise in $\mathrm{LH}$, reaching a maximum of $10.39 \pm 4.63 \mathrm{ng} \mathrm{ml}^{-1}$ (Fig. 3d). Forty-eight hours later, basal and post-GnRH testosterone concentrations were higher $(P<0.05)$ than in mannitoltreated controls (Fig. 3e). By day 20, basal testosterone concentrations had declined to values before Lupron Depot treatment; however, despite the small increase in GnRH-stimulated LH release, subsequent testosterone secretion increased 15 -fold (Fig. 3f).

In the one musth bull of Study 2, basal concentrations of serum LH and testosterone (Fig. 4a) were similar to those observed for the musth bull in Study I (Fig. 2a). An unexpected finding was that $\mathrm{LH}$ and testosterone concentrations were markedly reduced $48 \mathrm{~h}$ after D-mannitol control treatment (Fig. $4 b)$, similar to that observed for the Detirelix-treated musth bull (Fig. 2b). After the GnRH challenge, $\mathrm{LH}$ increased to a maximum of $5.23 \mathrm{ng} \mathrm{ml}^{-1}$, slightly higher than the average response observed for non-musth control bulls $\left(3.51 \pm 0.19 \mathrm{ng} \mathrm{ml}^{-1}\right.$; Fig. 3b), whereas testosterone secretion increased about 100fold over baseline concentrations (Fig. $4 \mathrm{~b}$ ). Two days after Lupron Depot treatment, basal $\mathrm{LH}$ and testosterone were raised and the responses to $\mathrm{GnRH}$ were minimal (Fig. 4c). By 20 days after Lupron Depot treatment, LH and testosterone concentrations were reduced to pre-Lupron Depot values. After the $\mathrm{GnRH}$ challenge, serum LH increased only slightly, to a peak of $1.15 \mathrm{ng} \mathrm{ml}^{-1}$, but subsequent testosterone secretion increased dramatically, exceeding $50 \mathrm{ng} \mathrm{ml}^{-1}$ (Fig. 4d). On the basis of temporal gland secretions and hind leg staining, this male remained in musth during the 2 days after Lupron Depot treatment, but was out of musth by day 22 . 

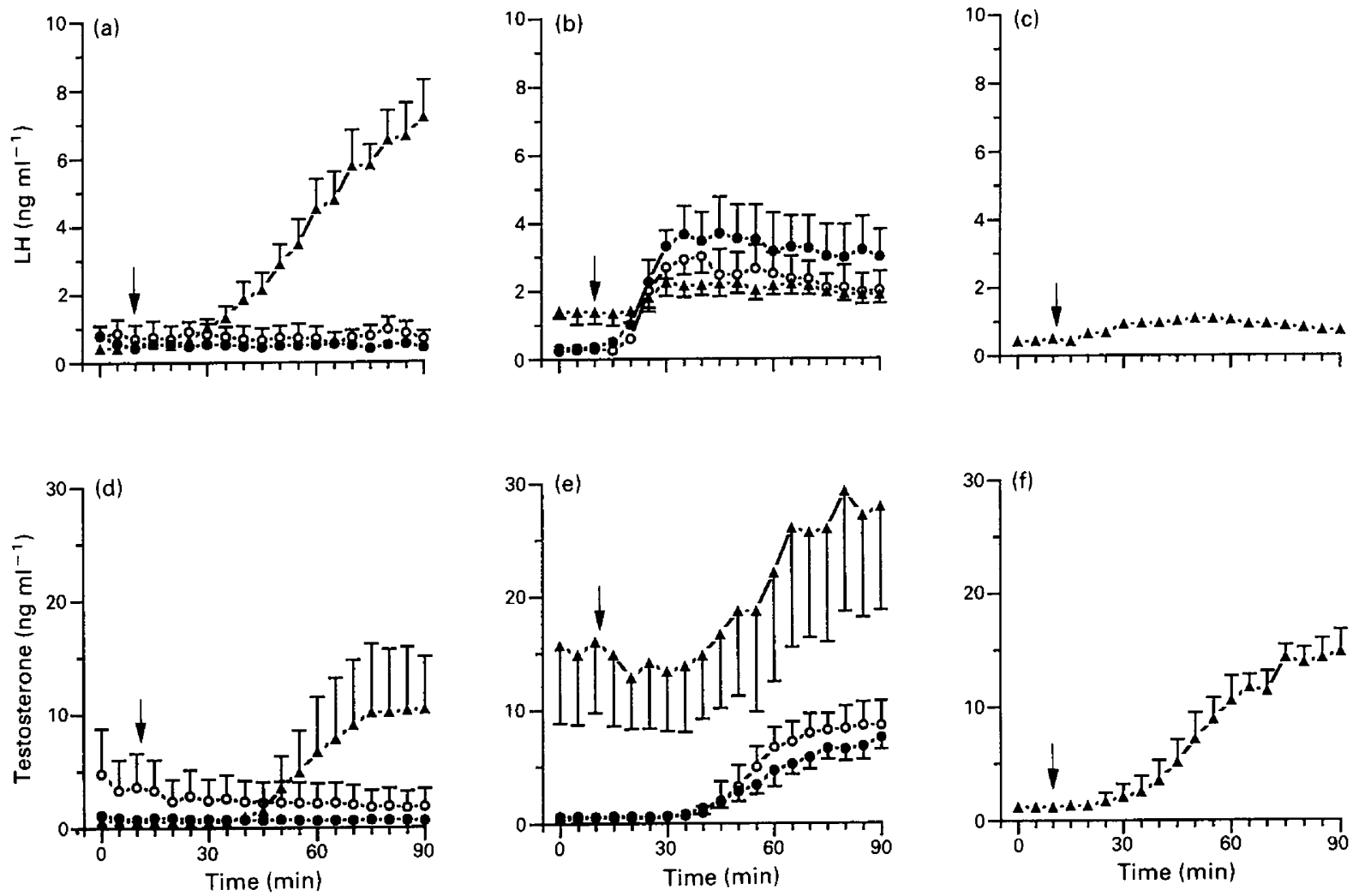

Fig. 3. Mean ( \pm SEM) serum $(a, b)$ LH and $(d, e)$ testosterone concentrations in non-musth bull elephants administered $(O)$ mannitol carrier $(n=4),(\mathbf{O}) \mathrm{GnRH}$ antagonist $(103-201-40 ; n=6)$ or $(\boldsymbol{\Delta}) \mathrm{GnRH}$ agonist (Lupron Depot; $n=4)$, i.m. on day 0 (a,d) and given GnRH ( $300 \mu \mathrm{g}$ i.v.) on day 2 (b,e). (c) and ( $f$ show LH and testosterone concentrations, respectively, after a GnRH challenge on day 20 for the Lupron Depot-treated group only. Blood samples were collected at intervals of 5 min for 90 min with all treatments administered after the third sample (arrow)

\section{Discussion}

Both GnRH agonists and antagonists suppress the pituitarygonadal axis, albeit via different mechanisms. Superactive GnRH agonists inhibit reproductive function by initially causing pituitary hyperstimulation followed by a decline in $\mathrm{LH}$ secretion as the gonadotrophs become desensitized (Karten and Rivier, 1986). The low dose requirements and long duration of action of the depot forms of GnRH agonists have made them popular therapeutic agents. However, when an immediate reduction in testosterone secretion is required, the initial transitory increase in gonadotrophin and subsequent testosterone secretion is an undesirable side-effect. Conversely, antagonist analogues of GnRH compete with endogenous GnRH for pituitary binding sites, resulting in an immediate suppression of gonadotrophin and gonadal steroid production (Karten and Rivier, 1986). Although higher and more frequent doses of antagonists are generally required, transient increases in hormone secretion are not observed, suggesting they may be more appropriate for acute therapeutic needs or when agonist treatment fails (Vickery, 1986).

Administering the $\mathrm{GnRH}$ antagonist Detirelix induces a rapid and sustained suppression of $\mathrm{LH}$ and testosterone secretion in many species (Weinbauer et al., 1984; see review, Vickery, 1985; Bremner ef al., 1991). Typically, Detirelix is administered daily (1-1700 $\mathrm{g} \mathrm{kg}^{-1}$ body weight), although its suppressive effects can last for up to $96 \mathrm{~h}$ after a single injection (Weinbauer et al., 1984; Vickery, 1985). We speculated that bull elephants might be highly sensitive to the suppressive effects of $\mathrm{GnRH}$ analogues because only a small amount of native $\mathrm{GnRH}(<0.05 \mu \mathrm{g}$ $\mathrm{kg}^{-1}$ ) is generally needed to maximally stimulate endogenous LH release (J. L. Brown, unpublished observations). However, acute administration of Detirelix $\left(0.8-2.4 \mu \mathrm{g} \mathrm{kg}^{-1}\right)$ resulted in only partial inhibition of $\mathrm{LH}$ and testosterone secretion two days after treatment. Unfortunately, Detirelix was unavailable for re-testing in Study 2; therefore, a structurally similar antagonist (103-201-40) was used. However, despite an increase in dose, this compound failed to inhibit pituitary LH secretion when examined $48 \mathrm{~h}$ after treatment. Although higher or more frequent doses might completely block pituitary activity, the data raise doubts about the practicality of these antagonists for long-term suppression of gonadal activity in elephants. The results also suggest that even minor differences in analogue structure can greatly influence physiological effectiveness, although we cannot rule out the possibility that differences in season, environment or vehicle may also have been a factor.

The GnRH agonist Lupron Depot is currently marketed for treating human prostate cancer because it inhibits testosterone secretion. In men, castrate concentrations of serum testosterone are achieved within two to four weeks and remain suppressed for at least 60 days after Lupron Depot injection (equivalent to $7.5 \mathrm{mg}$ leuprolide acetate) (J. Seeley, Takeda-Abbott, personal 

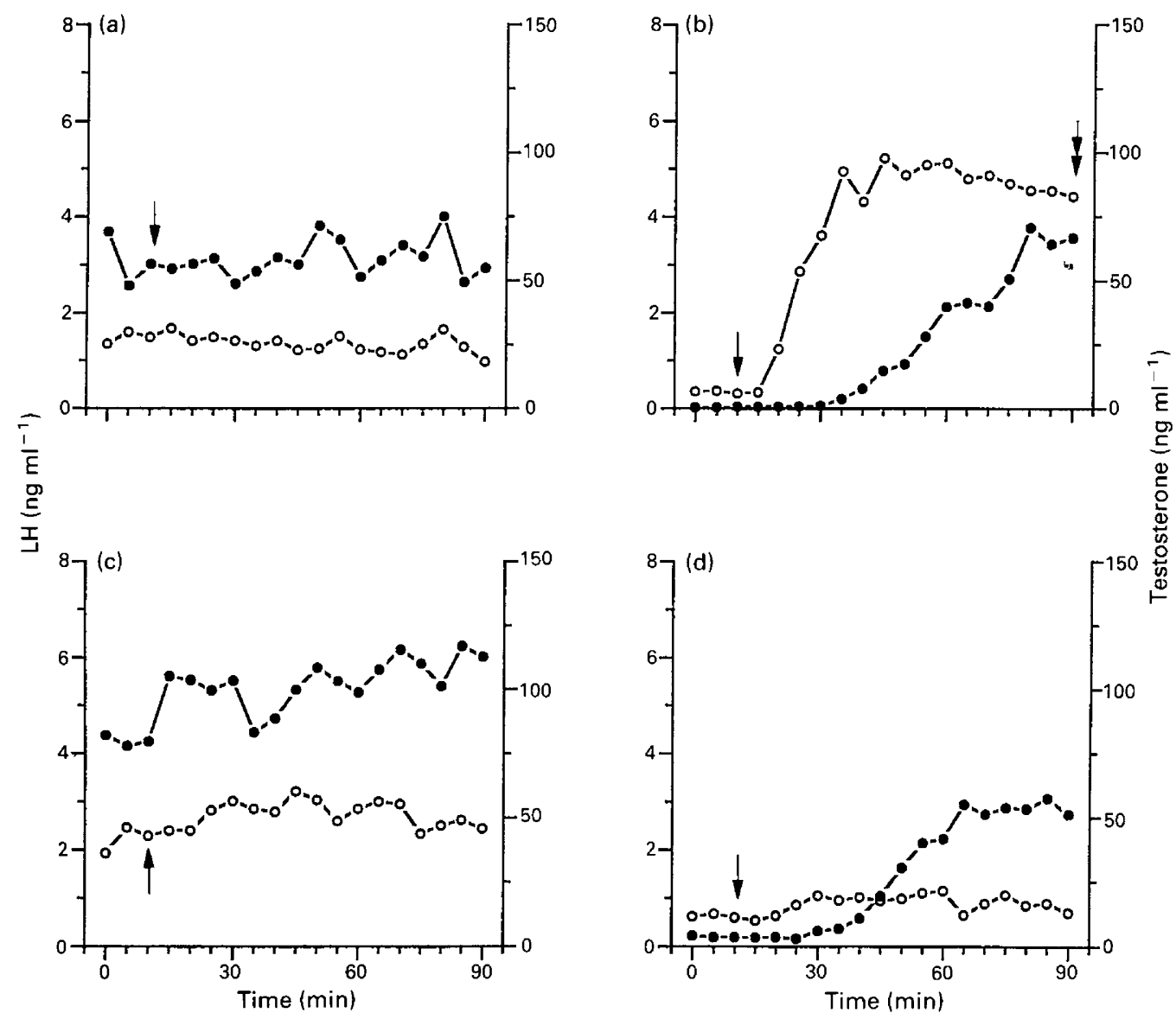

Fig. 4. Serum (O) LH and (O) testosterone concentrations in a musth bull elephant administered (a) mannitol carrier i.m. on day 0 and (b) given GnRH (300 $\mu$ i.v.) on day 2. This animal was then given Lupron Depot i.m. after the last blood sample on day 2 (double arrow) and GnRH challenges ( $300 \mu \mathrm{g}$, i.v.) on days 2 (c) and 20 (d) after Lupron Depot treatment. Blood samples were collected at intervals of 5 min for 90 min with mannitol and GnRH treatments administered after the third sample (arrow).

communication). In adult male elephants, Lupron Depot administration initially stimulated and then suppressed basal LH and testosterone secretion in a similar way to that described for primates and sheep (Resko et al., 1982; Mann et al., 1985; Lincoln et al., 1986). However, the pituitary was still responsive to GnRH 20 days after treatment, albeit weakly, as evidenced by a modest increase in $\mathrm{LH}$ release. The surprising observation was the magnitude of the resulting testosterone response. These data contrast with previous findings in rats which showed that GnRH agonist treatment inhibited testicular responsiveness by decreasing gonadal LH receptor concentrations and blocking the steroidogenic pathway at the 17hydroxylase and 17,20-desmolase steps (Belanger et al., 1979, 1980; Labrie et al., 1980; Seguin et al., 1981). However, in male rhesus monkeys and sheep, chronic $\mathrm{GnRH}$ agonist treatment decreased pituitary responsiveness without abolishing the testicular response to exogenous $\mathrm{LH}$ or $\mathrm{hCG}$, although testosterone secretion never exceeded that measured in controls (Resko et al., 1982; Mann et al., 1985; Lincoln et al., 1986). In this regard, our data more closely resemble those reported for beef bulls in which chronic administration of the GnRH agonists nafarelin acetate $\left(0.15 \mathrm{mg}\right.$ day $^{-1}$; Melson et al., 1986) or leuprolide (3.3 or $10 \mathrm{\mu g} \mathrm{kg}^{-1}$ body weight day ${ }^{-1}$; Ronayne $e t$ al., 1990) blocked pulsatile LH secretion, but induced significant increases in basal testosterone secretion. In the former study, the increase in testosterone secretion coincided with a more than threefold increase in testicular $\mathrm{LH}$ receptor concentrations (Melson et al., 1986). However, one major difference between elephants and bulls was that basal testosterone secretion was not increased in elephants. Instead, testicular hyperresponsiveness only became evident after $\mathrm{GnRH}$ treatment. However, it is possible that increased GnRH-induced testosterone secretion in agonist-treated elephants is related to increased testicular $\mathrm{LH}$ receptor binding.

It is clear that the mechanism of action of GnRH agonists is quite complex. While a disruption of normal hypothalamopituitary function is typically observed, testicular responsiveness can be inhibited, unaffected or even stimulated. These wide variations in response among the present and cited studies may be related to the use of different agonists, doses and treatment periods. Alternatively, there may be species differences in the pituitary-testicular response to these compounds. For example, in rats, direct agonist effects on the testis may be mediated through specific testicular GnRH receptors that are present in that species (Lefebvre et al., 1980), but lacking in others (mice, Hunter et al., 1982; humans and monkeys, Clayton and 
Huhtaniemi, 1982; bulls and sheep, J. L. Brown and B. E. Melson, unpublished observations). Unfortunately, the use of different agonists and experimental protocols precludes direct species comparisons at this time.

We would have preferred testing the GnRH analogues in more musth bulls. However, during the time we were in the field only one musth bull was found for each study. High concentrations of testosterone were measured in serum of both of these bulls, confirming our visual observations of musth and the existence of a relationship between high circulating androgens and these physical cues. In Study 1, administering Detirelix significantly reduced basal testosterone concentrations, suggesting that this compound might inhibit testicular function during musth. However, the pituitary response to GnRH was only partially blocked and it was clear that the testes were still capable of responding with substantial testosterone production even to a very modest increase in endogenous LH. Thus, as with non-musth bulls, higher doses or more frequent injection schedules may be needed to inhibit reproductive function completely. In Study 2, the musth bull was initially treated as a control. Surprisingly, basal testosterone concentrations in this animal were also reduced on day 2 , suggesting that anaesthesia or the stress of re-capture affected testicular function. This raised the question as to whether the observed inhibitory effects of $\mathrm{GnRH}$ analogues in non-musth bulls were due to treatment or the associated manipulation. However, pituitary-testicular function apparently was not significantly altered by capture or anaesthesia stress when data were compared between elephants evaluated after only a single anaesthetic episode (day o GnRH controls) and those subjected to repeated capture (Study 1 and 2 controls). Instead, it appears that perhaps only the testes of musth bulls are highly sensitive to these manipulatory procedures. Whether this effect is due to direct inhibitory effects of anaesthesia or stress hormones on the testis itself, to altered pulsatile gonadotrophin secretion, or to some other mechanism remains to be determined. In Asian elephants, increases in LH pulse area and amplitude, but not frequency, are observed during musth (Niemuller and Liptrap, 1991). It is also known that many anaesthetics, including etorphine as was used in this study, can block gonadotrophin pulsatility or reduce the frequency or amplitude of pulses (Peet and Lincoln, 1977; Clark and Doughton, 1983).

Another interesting observation in both musth bulls was the hyper-responsiveness of the testes to increases in $\mathrm{GnRH}$ induced $\mathrm{LH}$ concentration. Although basal testosterone concentrations were reduced to less than $4 \mathrm{ng} \mathrm{ml}^{-1}$ on day 2 , each animal responded to exogenous $\mathrm{GnRH}$ with a striking increase in testosterone secretion that greatly exceeded the responses of non-musth bulls. The cause of this increased testicular sensitivity to gonadotrophic stimulation is not immediately apparent, but again may be related to increased testicular LH-receptor binding. In other ungulate species, increased testosterone secretion during the breeding season or rut is known to be related to increased testicular $\mathrm{LH}$ receptor concentrations (Barenton and Pelletier, 1983; Brown et al., 1991). The fact that elephants in musth share many of the traits displayed by other mammalian species in rut (Poole, 1987) lends further support to this hypothesis.

In summary, because of the many management problems associated with musth, few male elephants are kept in captivity.
However, with numbers continuing to decline in the wild, a treatment that acutely suppresses cyclic musth behaviour would be a valuable regulatory tool for captive elephant breeding that would help perpetuate the species and maintain genetic diversity. The ability to prevent bulls from exhibiting aggressive (and dangerous) behaviour would allow more zoos to maintain male elephants and participate in propagation programmes. The results of this study suggest that GnRH analogues can disrupt normal pituitary function and may be useful to this end. It is clear, however, that controlling testosterone secretion in musth bulls will require further testing of other treatment regimens to block $\mathrm{LH}$ and subsequent testosterone secretion completely. Perhaps the greatest challenge will be dealing with the finding of testosterone hyper-responsiveness to even minute increases in pituitary LH. In a preliminary report, Miller et al. (1990) reported that a single injection of $45 \mathrm{mg}$ Lupron Depot (twice the dose used in this study) to a musth bull inhibited basal testosterone concentrations to castrate concentrations from day 10 to day 60 . However, although the visual signs of musth were attenuated, they were not completely alleviated. Perhaps the total elimination of musth behaviour will require the administration of an anti-androgen, such as cyproterone acetate or Danazol, to block the action of testosterone on behaviour as well as an inhibitor of pituitary-testicular function to reduce total testosterone output.

The authors thank D. Keet, D. Grobler, H. Wildi and J. Malan, Kruger National Park, RSA for assistance in all field operations, P. Otto and $\mathrm{H}$. Nierkirk for piloting the helicopters and M. Nelson and A. Mitchell for excellent technical assistance. This study was supported, in part, by Friends of the National Zoo (FONZ), New Opportunities for Animal Health Sciences (NOAHS) Center and the Ringling Brothers and Barnum and Bailey Circus. Blood samples were collected in full compliance with specific Federal US Fish and Wildlife permits issued to the National Zoological Park, Smithsonian Institution.

\section{References}

Barenton B and Pelletier J (1983) Seasonal changes in testicular gonadotropin receptors and steroid content in the ram Endocrinology 112 1141-1146

Belanger A, Auclair C, Seguin C, Kelly PA and Labrie F (1979) Down-regulation of testicular androgen biosynthesis and LH receptor levels by an LHRH agonist: role of prolactin Molecular and Cellular Endocrinology 13 47-53

Belanger A, Auclair C, Ferland L and Labrie F (1980) Time-course of the effects of treatment with a potent LHRH agonist on testicular steroidogenesis and gonadotropin receptor levels in the adult rat Joumal of Steroid Biochemistry 13 191-196

Bremner WJ, Bagatell CJ and Steiner RA (1991) Gonadotropin-releasing hormone antagonist plus testosterone: a potential male contraceptive Journal of Clinical Endocrinology and Metabolism 73 465-469

Brown JL, Goodrowe KL, Simmons LG, Armstrong DL and Wildt DE (1988) Evaluation of the pituitary-gonadal response to $\mathrm{GnRH}$, and adrenal status, in the leopard (Panthera pardus japonensis) and tiger (Panthera tigris) Journal of Reproduction and Fertility 82 227-236

Brown JL, Wildt DE, Raath JR, de Vos V, Janssen DL, Citino SB, Howard JG and Bush M (1991) Seasonal variation in pituitary-gonadal function in freeranging impala (Aepyceros melampus) Journal of Reproduction and Fertility $\mathbf{9 3}$ 497-505

Clark IJ and Doughton BW (1983) Effect of various anaesthetics on resting plasma concentrations of luteinizing hormone, follicle-stimulating hormone and prolactin in ovariectomized ewes Journal of Endocrinology 98 79-89

Clayton RN and Huhtaniemi IT (1982) Absence of gonadotropin-releasing hormone receptors in human gonadal tissue Nature 299 56-59 
Cooper KA, Harder JD, Clawson DH, Frederick DL, Lodge GA, Peachey HC, Spellmire TJ and Winstel DP (1990) Serum testosterone and musth in captive male African and Asian elephants Zoo Biology 9 297-306

Eisenberg JF, McKay GM and Jainudeen MR (1971) Reproductive behaviour of the Asiatic elephant (Elephas maximus L.) Behaviour 38 193-217

Hall-Martin AJ (1987) Role of musth in the reproductive strategy of the African elephant (Loxodonta africana) South African Journal of Science 83 616-620

Hall-Martin AJ and van der Walt LA (1984) Plasma testosterone levels in relation to musth in the male African elephant Koedoe 27 147-149

Howard JG, Bush M, deVos V and Wildt DE (1984) Electroejaculation, semen characteristics and serum testosterone concentrations of free-ranging African elephants (Loxodonta africana) Journal of Reproduction and Fertility 72 187-195

Hunter MG, Sullivan MHF, Dix CJ, Aldred LF and Cooke BA (1982) Stimulation and inhibition by LHRH analogs of cultured rat Leydig cell function and lack of effect on mouse Leydig cells Molecular and Cellular Endocrinology 27 31-44

Jainudeen MR, McKay GM and Eisenberg JF (1972a) Observations on musth in the domesticated Asiatic elephant (Elephas maximus) Mammalia 36 247-261

Jainudeen MR, Katongole CB and Short RV (1972b) Plasma testosterone levels in relation to musth and sexual activity in the male Asiatic elephant, Elephas maximus Journal of Reproduction and Fertility 29 99-103

Karten MJ and Rivier JE (1986) Gonadotropin-releasing hormone analog design. Structure-function studies toward the development of agonists and antagonists Endocrine Reviews 7 44-66

Labrie F, Cusan L, Seguin A, Belanger A, Pelletier J, Reeves JJ, Kelly PA, Lemay A and Renaud JP (1980) Antifertility effects of LHRH agonists in the male rat and inhibition of testicular steroidogenesis in man International journal of Fertility 25 157-161

Lefebvre FA, Reeves JJ, Seguin C, Massicotte J and Labrie F (1980) Specific binding of a potent LHRH agonist in rat testis Molecular and Cellular Endocrinology 20 127-134

Lincoln GA, Fraser HM and Abbott MP (1986) Blockade of pulsatile LH, FSH and testosterone secretion in rams by constant infusion of an LHRH agonist Joumal of Reproduction and Fertility 77 587-597

Mann DR, Smith MM, Gould KG and Collins DC (1985) Effect of a gonadotropinreleasing hormone agonist on luteinizing hormone and testosterone secretion and testicular histology in male rhesus monkeys Fertility and Sterility $\mathbf{4 3}$ $115-121$

Melson BE, Brown JL, Schoenemann HM, Tarnavsky GK and Reeves JJ (1986) Elevation of serum testosterone during chronic LHRH agonist treatment in the bull Joumal of Animal Science 62 199-207

Miller JD, Schmidt MJ and Hess D (1990) Leuprolide acetate attenuates elephant musth: a paradigm for the treatment of sex-hormone related behaviors 37 th Annual Meeting: Society for Gynecologic Investigation p 212 Ed. RA Lobo Abstract 231 Elsevier Science Publishers, New York

Niemuller CA and Liptrap RM (1991) Altered androstenedione to testosterone ratios and LH concentrations during musth in the captive male Asian elephant (Elephas maximus) Journal of Reproduction and Fertility 91 139-146
Pavlou SN, Brewer K, Farley MG, Lindner J, Bastias MC, Rogers BJ, Swift LL, Rivier JE, Vale WW, Conn PM and Herbert CM (1991) Combined administration of a gonadotropin-releasing hormone antagonist and testosterone in men induces reversible azoospermia without loss of libido Journal of Clinical Endocrinology and Metabolism 73 1360-1369

Peet MJ and Lincoln GA (1977) Blockade of episodic gonadotrophin secretion by Immobilon in ovariectomized ewes Journal of Reproduction and Fertility $\mathbf{5 0}$ 97-100

Poole JH (1987) Rutting behavior in African elephants: the phenomenon of musth Behaviour 102 283-316

Poole JH (1989a) Announcing intent: the aggressive state of musth in African elephants Animal Behaviour 37 140-152

Poole JH (1989b) Mate guarding, reproductive success and female choice in African elephants Animal Behaviour $37842-849$

Poole JH and Moss CJ (1981) Musth in the African elephant, Loxodonta africana Nature 292 830-831

Rasmussen LE, Buss IO, Hess DL and Schmidt MJ (1984) Testosterone and dihydrotestosterone concentrations in elephant serum and temporal gland secretions Biology of Reproduction 30 352-362

Resko JA, Belanger A and Labrie F (1982) Effects of chronic treatment with a potent luteinizing hormone releasing hormone agonist on serum luteinizing hormone and steroid levels in the male rhesus monkey Biology of Reproduction 26 378-384

Ronayne E, Enright WJ and Roche JF (1990) Effect of continuous administration of gonadotrophin-releasing hormone $(\mathrm{GnRH})$ and a potent $\mathrm{GnRH}$ analogue on blood luteinizing hormone (LH) and testosterone (T) concentrations in prepubertal bulls Journal of Reproduction and Fertility Abstract Series 5 Abstract 44

Seguin C, Belanger A, Cusan L, Pelletier G, Reeves JJ, Lefebvre F, Kelly PA and Labrie F (1981) Relative importance of the adenohypophyseal and gonadal sites of inhibitory action of LHRH agonists Biology of Reproduction 24 889-901

Vickery BH (1985) Comparisons of the potential utility of LHRH agonists and antagonists for fertility control Journal of Steroid Biochemistry 23 779-791

Vickery BH (1986) Comparison of the potential for therapeutic utilities with gonadotropin-releasing hormone agonists and antagonists Endocrine Reviews 7 115-124

Vickery BH, McRae GI, Briones W, Worden AC, Seidenberg R, Schanbacher BD and Falvo $\mathbf{R}$ (1984) Effects of an LHRH agonist analog upon sexual function in male dogs: suppression, reversibility and effect of testosterone replacement Journal of Andrology 5 28-42

Weinbauer GF, Surmann FJ, Akhtar FB, Shah GV, Vickery BH and Nieschlag E (1984) Reversible inhibition of testicular function by a gonadotropin hormonereleasing hormone antagonist in monkeys (Macaca fascicularis) Fertility and Sterility 42 906-914 